\title{
Impact of Solar Planet on Coronavirus (COVID-19) Outbreak
}

\author{
Agrim Subedi" ${ }^{1}$, Madhav Raj Pandey ${ }^{2}$, Sahadev Bistha ${ }^{3}$, Catalino Dotollo Jr. ${ }^{4}$, \\ Feliciano Jonh Matibag Jr. ${ }^{4}$, Lok Raj Poudel ${ }^{5}$, Krishna Prasad Subedi ${ }^{5}$ \\ ${ }^{1}$ Om Shanty Academy, Bharatpur, Chitwan, Nepal \\ ${ }^{2}$ Astro Council Nepal \\ ${ }^{3}$ south Asian Astro Fedration \\ ${ }^{4}$ Southwestern University, Philippines \\ ${ }^{5}$ World Astro Fedration \\ *Corresponding Author :- agrimsubedi527@gmail.Com
}

\begin{abstract}
Article Info
Volume 7, Issue 6

Page Number: 425-430

Publication Issue :
\end{abstract}

November-December-2020

\section{Article History}

Accepted : 12 Dec 2020

Published : 30 Dec 2020

\section{ABSTRACT}

Astrology is a science which searches the mysteries of the possibilities that are likely to occur in the future. This study has tried to clarify how the planets are responsible to produce any kind of disease in the person. The random samplings of the individuals attending hospital for diagnosis of coronavirus were included in this study. Total twenty Covid - 19 patients were selected for the horoscope. The horoscope was prepared on the date and the time of birth of the CoViD - 19 patients recorded by them which was approved by Nepal Panchanga Nirnayak Committee. In majority of covid patients, the Rahu which is the causal-factor of virus.

But at the same time it has been seen that the person having good DasaAntardasa also suffered with COVID - 19 due to his individuals behavior. Among the 20 cases, Majority of them had unfavorable Dasa - Antardasa and unfavorable condition of Rahu which is vital factor for the disease i.e. coronavirus. The effect of solar planets had been seen in human health. The immunity power becomes weak due to the weakness of Lagnes and there is high chances to become ill, if the Dasa- Antardasa is unfavorable.

Keywords : Astrology, COVID -19, Corona virus, Pandemic, Planets

\section{INTRODUCTION}

Novel Coronavirus (COVID-19) is the most recent one in the world Firstly; it was detected in Wuhan city of China in December, 2019 and became pandemic in the short span of time. Since the pandemic of COVID-19 is alarming the globe, the number of infected cases around the world is increasing day by day[1].

History of human corona virus started in 1965 with the first coronavirus B814. It was discovered by Tyrell and Byoe. It was detected in the trachea of the respiratory tract in an adult who was suffering from common cold[2]. Since then different forms of corona 
virus exit in this earth. Recently, the world is under the epidemic of new type of coronavirus (COVID-19) which is believed to be worldwide through its origination in Wuhan, China. Till now it has reached to across the globe. It is also a virus that is transmitted through contact with an infected person[2]. This contact can be through respiratory droplets or salivary droplets during the coughing or sneezing of the infected person[3]. It has led to high mobility and mortality rate in China, Europe, United States and most of the other countries in the world[4]. It has lead to unprecedented health crises throughout the world. Many people are dying because of disease and hunger in the world due to corona virus. So on March 11, 2020 the world health organization (WHO) declared COVID-19 as a global pandemic. COVID 19 is caused by a novel corona virus which is also known as severe acute respiratory syndrome coronavirus (SARS-COV-2) [5, 6]. Although the large numbers of individuals infected with COVID-19 globally, it is bitter fact that there is no medicine invented by now. Medical astrology is an ancient medical system that associates various parts of the body, diseases, and drugs as under the influence of the sun, moon, and planets, along with the twelve astrological signs. It searches the mysteries of the possibilities of diseases that are likely to occur in the future. All the planets have more or less effects on every men.

Study conducted by Subedi et al. 2019 showed the relationship of medical and astrological science to clarify how the planets are responsible to produce, cancer and other disease in the person. It also displayed the relationship between the medical astrology with corona virus.

\section{METHODS AND MATERIAL}

Total 20 patients has been taken for this study. Each individuals were randomly visited in the study period. Main instrument for the study were laboratory report with and individuals horoscope made based on the calendar issued by Nepal Panchanga Niryanak Committee. The prediction had been done on the basis of the Falit Jyotish.

\section{III.LIMITATION OF THE STUDY}

This study has the inclusion of total 20 persons having Covid 19 problem. This study being the inclusion of limited Covid 19 patients may not fully be accepted in general but it is hoped to be an extra study and research from the point of medical and astrological perspective.

\section{RESULTS AND DISCUSSION}

This study explains the total 20 patients. All patients were analyzed by medical and astrological sciences and noted the result as below.

\section{RESULT COVID \& ASTROLOPGY}

\begin{tabular}{|l|l|l|l|l|l|l|l|l|l|}
\hline \multicolumn{9}{|c|}{ Distribution of Cases Based on Medical \& Astrological Perspective } \\
\hline S.N. & $\begin{array}{l}\text { Case } \\
\text { No. }\end{array}$ & Sex & $\begin{array}{l}\text { Native } \\
\text { status }\end{array}$ & Lagnes & Roges & Astames & Dasa & $\begin{array}{l}\text { Antar- } \\
\text { dasa }\end{array}$ & Remarks \\
\hline 1 & 1 & Male & $\begin{array}{l}\text { COViD } \\
-19+\text { ve }\end{array}$ & Mercury & Saturn & Mars & Jupitor & Venus & $\begin{array}{l}\text { Marak Dasa } \\
\text { weaked } \\
\text { Lagnes }\end{array}$ \\
\hline 2 & 2 & Male & $\begin{array}{l}\text { COViD } \\
-19+\text { ve }\end{array}$ & Mars & Mars & Mercury & Saturn & $\begin{array}{l}\text { Rahu } \\
\text { Lagnes co- } \\
\text { jointly with } \\
\text { Rahu in }\end{array}$ \\
\hline
\end{tabular}




\begin{tabular}{|c|c|c|c|c|c|c|c|c|c|}
\hline & & & & & & & & & $\begin{array}{l}\text { Saturn"s } \\
\text { house }\end{array}$ \\
\hline 3 & 3 & Male & $\begin{array}{l}\text { COViD } \\
-19+\mathrm{ve}\end{array}$ & Mercury & Saturn & Mars & Saturn & sun & $\begin{array}{l}\text { Lagnes in } 12^{\text {th }} \\
\text { house\& fully } \\
\text { sighted by } \\
\text { Ketu }\end{array}$ \\
\hline 4 & 4 & Female & $\begin{array}{l}\text { COViD } \\
-19+\mathrm{ve}\end{array}$ & Saturn & Moon & Mercury & Rahu & Ketu & $\begin{array}{l}\text { Lagnes in } \\
\text { sinfull- } \\
\text { kartari, Rahu } \\
\text { \& Ketu with } \\
\text { Dasa- } \\
\text { Antardasa }\end{array}$ \\
\hline 5 & 5 & Female & $\begin{array}{l}\text { COViD } \\
-19+\mathrm{ve}\end{array}$ & Saturn & Mercury & Sun & Moon & Jupiter & $\begin{array}{l}\text { Normal Dasa- } \\
\text { antardasa }\end{array}$ \\
\hline 6 & 6 & Male & $\begin{array}{l}\text { COViD } \\
-19+\mathrm{ve}\end{array}$ & Jupiter & Venus & Moon & Jupiter & Rahu & $\begin{array}{l}\text { Lagnes with } \\
\text { Rahu, Jupiter } \\
\& \text { Rahu in } \\
\text { Dasa- } \\
\text { Antarsdasa }\end{array}$ \\
\hline 7 & 7 & Male & $\begin{array}{l}\text { COViD } \\
-19+\mathrm{ve}\end{array}$ & Mars & Mars & Mercury & Ketu & Saturn & $\begin{array}{l}\text { Roges in } \\
\text { Lagna, } \\
\text { weakness of } \\
\text { Lagna, Ketu \& } \\
\text { Saturn in } \\
\text { Dasa- } \\
\text { Antardasa }\end{array}$ \\
\hline 8 & 8 & Male & $\begin{array}{l}\text { COViD } \\
-19+\mathrm{ve}\end{array}$ & Venus & Venus & Jupiter & Venus & Jupiter & $\begin{array}{lr}\text { Lagnes } & \text { \& } \\
\text { Roges } & \text { with } \\
\text { Mars, } & \\
\text { Astames } & \text { in } \\
\text { Lagna. } & \\
\end{array}$ \\
\hline 9 & 9 & Male & $\begin{array}{l}\text { COViD } \\
-19+\mathrm{ve}\end{array}$ & Venus & Venus & Jupiter & Rahu & Saturn & $\begin{array}{lr}\text { Lagnes with } \\
\text { Ketu, Rahu - } \\
\text { Mars co- } \\
\text { jointly } \\
\end{array}$ \\
\hline 10 & 10 & Female & $\begin{array}{l}\text { COViD } \\
-19+\mathrm{ve}\end{array}$ & Moon & Jupiter & Saturn & Venus & Venous & $\begin{array}{lr}\text { Lagness } & \text { fully } \\
\text { sighted } & \text { by } \\
\text { Rahu } & \end{array}$ \\
\hline 11 & 11 & Male & $\begin{array}{l}\text { COViD } \\
-19+\mathrm{ve}\end{array}$ & Mercury & Mars & Saturn & Saturn & Moon & 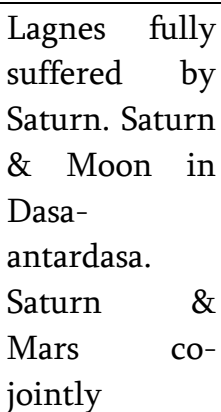 \\
\hline 12 & 12 & Female & $\begin{array}{l}\text { COViD } \\
-19+\mathrm{ve}\end{array}$ & Sun & Saturn & Jupiter & Saturn & Mercury & $\begin{array}{l}\text { Lagnes } \\
\text { sighted by } \\
\text { Ketu. } \\
\end{array}$ \\
\hline 13 & 13 & Male & COViD & Mars & Mars & Mercury & Jupiter & Ketu & Jupiter \\
\hline
\end{tabular}




\begin{tabular}{|c|c|c|c|c|c|c|c|c|c|}
\hline & & & $-19+\mathrm{ve}$ & & & & & & Ketu in Dasa- \\
\hline 14 & 14 & Male & $\begin{array}{l}\text { COViD } \\
-19+\mathrm{ve}\end{array}$ & Venus & Jupiter & Venous & Ketu & Venous & $\begin{array}{lr}\text { Mars } & \text { in } \\
\text { Lagna, Loard } \\
\text { of } 8^{\text {th }} \text { in Lagna }\end{array}$ \\
\hline 15 & 15 & Female & $\begin{array}{l}\text { COViD } \\
-19+\mathrm{ve}\end{array}$ & Mars & Mars & Mercury & Jupiter & Mercury & $\begin{array}{l}\text { Narmal Dasa- } \\
\text { Antardasa }\end{array}$ \\
\hline 16 & 16 & Male & $\begin{array}{l}\text { COViD } \\
-19+\mathrm{ve}\end{array}$ & Saturn & Moon & Mercury & Rahu & Venus & $\begin{array}{lr}\text { Rahu } & \& \\
\text { Venous } & \text { in } \\
\text { Dasa- } & \\
\text { Antardasa } & \\
\end{array}$ \\
\hline 17 & 17 & Male & $\begin{array}{l}\text { COViD } \\
-19+\mathrm{ve}\end{array}$ & Sun & Saturn & Jupiter & Sun & Moon & $\begin{array}{lr}\text { Lagnes with } \\
\text { Ketu. Lagna } \\
\text { suffered by } \\
\text { Rahu }\end{array}$ \\
\hline 18 & 18 & Female & $\begin{array}{l}\text { COViD } \\
-19+\mathrm{ve}\end{array}$ & Sun & Saturn & Jupiter & Saturn & Jupiter & $\begin{array}{lr}\text { Lagnes in } \\
\text { Disease house } \\
\text { and fully } \\
\text { sighted } \\
\text { Saturn }\end{array}$ \\
\hline 19 & 19 & Male & $\begin{array}{l}\text { COViD } \\
-19+\mathrm{ve}\end{array}$ & Saturn & Saturn & Mars & Moon & Ketu & $\begin{array}{l}\text { Lagnes'Saturn' } \\
\text { with Jupiter } \\
\text { suffered by } \\
\text { Mars }\end{array}$ \\
\hline 20 & 20 & Female & $\begin{array}{l}\text { COViD } \\
-19+\mathrm{ve}\end{array}$ & Mercury & Saturn & Mars & Venus & Jupiter & $\begin{array}{l}\text { Lagnes with } \\
\text { Mars suffered } \\
\text { by Saturn }\end{array}$ \\
\hline
\end{tabular}

1. The Lagnes 'Mercury' situated at $11^{\text {th }}$ house in Cancer which was fully suffered by Saturn. Whereas, Jupitor gives full sight to Mercury in cancer jodiac.. The Roges 'Saturn' placed at $2^{\text {nd }}$ house with Moon and Ketu in Libra and fully sighted by Mars. The Astames 'Mars' co-jointly placed with Sun "Lord of $12^{\text {th }}$ house" in Gemin.

2. The Lagnes 'Mars' co-jointly present with Rahu in Carpicorn and fully sighted by Ketu. Whereas, Mars consider as a Roges. The Astames was Mercury placed at $12^{\text {th }}$ house and sighted by Rahu.

3. The Lagnes 'Mercury' placed at $2^{\text {nd }}$ house in Libra and fully suffered by Mars. Whereas, the Mars also known as Astames. The Roges 'Saturn' places with Rahu \& Jupitor placed at $12^{\text {th }}$ house in Leo.

4. The Lagnes 'Saturn' placed at $10^{\text {th }}$ house as a kartari "in between sinful planet" position in Scorpio. The roges Moon placed with Rahu and
Venus in $3^{\text {rd }}$ house in Aries and sighted by Ketu. Astames 'Mercury' co-jointly placed with sun at $2^{\text {nd }}$ house in Pisces.

5. The Lagnes 'Saturn' places at $10^{\text {th }}$ house with Roges ' Mercury" and astames 'Sun' in Libra.

6. The Lagnes Jupitor placed at $10^{\text {th }}$ house with Sun, Saturn and Mercury in Virgo. Roges 'Venus' placed at $12^{\text {th }}$ house in Scorpio. Astames 'Moon' co-jointly placed at $2^{\text {nd }}$ house and sighted by Rahu.

7. The Lagnes \& Roges 'Mars' placed at Lagna in Scorpio. Astames 'Mercury' placed at $12^{\text {th }}$ house with Sun and Venus in Libra.

8. The Rahu situated at $6^{\text {th }}$ house, Lagnes 'Venus' placed at $5^{\text {th }}$ house with Mars and Mercury in Leo. Astames 'Jupiter' placed at Lagna in Taurus.

9. The Lagnes and Roges 'Venus' placed at $10^{\text {th }}$ house in Aqua ffered by Mars. 
10.The Lagnes 'Moon' placed at 9th house in Pisces. The Astames Saturn placed at $4^{\text {th }}$ house in Libra and sighted by Rahu.

11.The Lagnes 'Mercury' placed at $10^{\text {th }}$ house in Pisces. Roges 'Mars' co-jointly places with Saturn at Lagna in Gemini.

12. The Lagnes Sun co-jointly placed with Rahu at $12^{\text {th }}$ house in Cancer and fully suffered by Ketu. Roges 'Saturn' and Astames 'Jupitor' place with Venus at $2^{\text {nd }}$ house in Virgo.

13.The Lagnes and Roges 'Mars' placed at $9^{\text {th }}$ house in Cancer and sighted by Ketu. Astames 'Mercury' placed at $2^{\text {nd }}$ house in Sagittarius.

14. The Lagnes and Astames 'Venus' co-jointly placed at Lagna in Libra and sighted by Rahu. Roges Jupitor placed at $10^{\text {th }}$ house in Cancer. Rahu placed at $8^{\text {th }}$ house and fully sighted by Mars.

15.The Lagnes and Roges 'Mars' placed at $5^{\text {th }}$ house in Pisces. Astames 'Mercury' placed with Sun in $7^{\text {th }}$ places in Taurus. Jupitor placed at $8^{\text {th }}$ house which was fully sighted by Saturn.

16.Lagnes 'Saturn' placed at $12^{\text {th }}$ house in Capricorn. Roges 'Moon' placed at $8^{\text {th }}$ house in Virgo. Astames ' Mercury' placed with Mara and Venus at $10^{\text {th }}$ house in Scorpio.

17.The Lagnes sun placed at 9th house in Aries and suffered by Rahu. Roges 'Saturn' co-jointly placed with Mars at $12^{\text {th }}$ house in Cancer.

18.The Lagnes Sun placed at $6^{\text {th }}$ house in Capricorn and suffered by Saturn. Jupitor, Mars and Rahu placed at $8^{\text {th }}$ house in Pisces. Whereas, the Lord of $8^{\text {th }}$ placed in same Zodiac.

19.The Lagnes 'Saturn' co-jointly placed with Jupiter at $9^{\text {th }}$ house in Virgo which sighted by Mars. Roges 'Mercury' placed at $2^{\text {nd }}$ house in Aquarius. Astames 'Sun' placed with Mars and Venus at $3^{\text {rd }}$ house in Pisces.

20.The Lagnes 'Mercury' Roges 'Saturn' and Astames 'Mars' placed at $11^{\text {th }}$ house in Cancer

\section{Discussion}

The effect of solar planets had been seen in human health. The immunity power become weak due to the weakness of Lagnes and there is high chances to become ill, if the Dasa Antardasa is unfavorable. But at the same time it has been seen that the person having good Dasa Antardasa also suffered with COVID 19 due to his individuals behavior. Among the 20 cases, Majority of them had unfavorable dasa Antardasa and unfavorable condition of Rahu which is vital factor for the disease i.e. coronavirus.

\section{Conclusion}

From the above study we can conclude that with the mere study of corona patient does not proved that corona was caused due to the effect of solar planet only.

\section{VII.Acknowledgements}

The author would like to offer thank to all of patients and relevant persons for providing valuable information towards this research.

\section{REFERENCES}

[1]. Poudel MP, Trend Analysis of Infected Cases with Corona Virus in Nepal by Using Polyno Regression Model, www.jetir.org, Volume 7, Issue 9 (C) 2020 JETIR

[2]. Tyrrell, D. A. J., and M. L. Bynoe. "Cultivation of viruses from a high proportion of patients with colds." Lancet (1966): 76-7.

[3]. He, Sha, Sanyi Tang, and Libin Rong. "A discrete stochastic model of the COVID-19 outbreak: Forecast and control." Math. Biosci. Eng 17 (2020): 2792-2804.

[4]. Kahn, Jeffrey S., and Kenneth McIntosh. "History and recent advances in coronavirus discovery." 
The Pediatric infectious disease journal 24.11 (2005): S223-S227.

[5]. Wang, Jin. "Mathematical models for COVID-19: Applications, limitations, and potentials." Journal of public health and emergency 4 (2020).

[6]. Gilbert, Marius, et al. "Preparedness and vulnerability of African countries against importations of COVID19: a modelling study." The Lancet 395.10227 (2020): 871-877.

\section{Cite this article as :}

Agrim Subedi, Madhav Raj Pandey, Sahadev Bistha, Catalino Dotollo Jr., Feliciano Jonh Matibag Jr., Lok Raj Poudel, Krishna Prasad Subedi "Impact of Solar Planet on Coronavirus (COVID-19) Outbreak ", International Journal of Scientific Research in Science and Technology (IJSRST), Online ISSN : 2395-602X, Print ISSN : 2395-6011, Volume 7 Issue 6, pp. 425-430, November-December 2020. Available at doi : https://doi.org/10.32628/IJSRST207646

Journal URL : http://ijsrst.com/IJSRST207646 